\title{
EFFECT OF DIETARY GRAPE AND POMEGRANATE SEED OIL ON THE POST-SLAUGHTER VALUE AND PHYSICOCHEMICAL PROPERTIES OF MUSCLES OF BROILER CHICKENS
}

\author{
Teresa Banaszkiewicz ${ }^{1 凶}$, Agnieszka Białek², Andrzej Tokarz², Karol Kaszperuk³ \\ ${ }^{1}$ Faculty of Natural Science, University of Natural Sciences and Humanities in Siedlce \\ Prusa 14, 08-110 Siedlce, Poland \\ ${ }^{2}$ Department of Bromatology, Warsaw Medical University \\ Banacha 1, 02-097 Warsaw, Poland \\ ${ }^{3}$ Department of Animal Nutrition and Feed Management, University of Natural Sciences and Humanities in Siedlce \\ Prusa 14, 08-110 Siedlce, Poland
}

\begin{abstract}
Background. The purpose of the study was to evaluate the post-slaughter value and quality of broiler chicken meat, and the possibility of enriching it with health-promoting fatty acids.

Material and methods. The experiment was carried out on 108 sexed broiler chickens (Ross 308). For the first 21 days of their lives, the chickens received the same diet, and after 21 days the chickens were divided into 3 groups of 36 birds (six replicate pens with 6 birds per pen comprised one experimental group), and fed the experimental diets until the 42nd day. The experimental diets were wheat-corn-soybean diets with soybean oil ( $5 \%$ control), grape seed oil or pomegranate seed oil. The grape seed oil and pomegranate seed oil replaced $2 \%$ of the soybean oil in the control diet. On day 42, the broilers were slaughtered and post-slaughter tests were performed. Samples of breast and thigh muscle were collected for basic chemical composition, physical characteristics, fatty acid profile, malondialdehyde content and sensory evaluation.

Results. The source of the oils did not significantly alter the slaughter yield, basic nutrients and physical characteristics of the breast and thigh muscles, but pomegranate seed oil significantly improved the palatability of thigh muscles. Grape seed oil and pomegranate seed oil influenced the fatty acid profile of the meat. The grape seed oil significantly decreased saturated fatty acids (palmitic) in muscles. The inclusion of pomegranate seed oil resulted in the deposition of a small amount of punicic acid, while significantly increasing rumenic acid. The inclusion of $2 \%$ grape seed oil in the broilers' diet significantly increased the sum of the n- 6 fatty acids and the ratio of n-6 to n-3 relative to the control group. Punicic acid - contained in the pomegranate seed oil - was effectively converted to rumenic acid, indicating the possibility of enriching the meat with these acids and increasing the health-promoting properties of broiler' meat.

Conclusion. Grape and pomegranate seed oil are potentially promising additives which could improve the fatty acid profile of poultry meat. The inclusion of grape and pomegranate seed oils into the feed is one way to improve the quality of broiler chicken meat and the derived "functional food". It could also be a way to give people better quality food without changing their eating habits.
\end{abstract}

Keywords: broiler chickens, pomegranate seed oil, grape seed oil, post-slaughter results, meat quality

The project was financed by Ministry of Science and Higher Education under a number 223/05/S and 92/14/MN.

凶banaszt@uph.edu.pl 


\section{INTRODUCTION}

Due to the scientifically proven role of the so-called western diet in the development of many metabolic disorders which may be the basis for the development of the so-called "diseases of civilization", more and more attention has been paid to the functional properties of food, i.e. those properties that have a positive effect on the health (Attia et al., 2010). Food may gain these properties from various bioactive substances, such as certain unsaturated fatty acids. These acids have health-promoting properties and can be effective in the prevention of many chronic diseases (Attia et al., 2015; 2017a). In human diets, especially in developed countries, there is a deficiency of unsaturated, especially polyunsaturated, fatty acids, which - when combined with an increase in saturated fatty acids increases the susceptibility to dietary-related illnesses. Recently, increasing interest has also been paid to polyunsaturated fatty acids containing conjugated systems. Examples of such acids include conjugated linoleic acid dienes (CLA), especially cis-9, trans-11 and trans-10, cis-12 isomers and conjugated linolenic acid trienes (CLnA): cis-9, trans-11, cis-13 (punicic acid), which have numerous health-promoting properties (Attia et al., 2017b). Research on laboratory animals has shown that acids containing conjugated bonds have anti-cancer, anti-atherosclerosis and antiinflammatory properties, reduce fatty tissue, increase muscle mass and stimulate the growth of the body through e.g. increased bone mass gain (Abrones-Mainar et al., 2006; Bhattacharya et al., 2006). Research is, therefore, being undertaken to increase the content of nutritionally valuable substances, including polyunsaturated fatty acids, in products of animal origin. Meat from broiler chickens is one of the first choices for consumers worldwide due to its high availability and relativity low price. Poultry is a good matrix, both for food enrichment and the production of "functional foods". Recently, more and more research has focused on the enrichment of meat with polyunsaturated fatty acids as well CLA and CLnA conjugate acids. Significant improvements in the functional value of poultry was obtained by the incorporation of rapeseed oil into the diet of broiler chickens (Banaszkiewicz 2002; Jankowski et al., 2012), fish oil (Lopez-Ferrer et al., 2001) and grape seed oil (Bail et al., 2008; Chaînier et al., 2000). One good source of polyunsaturated acids is pomegranate and grape seed oils, which also have antioxidant effects. The grape (Vitisvinifera L., Vitaceae) is one of the most common fruit crops in the world and is a source of many bioactive compounds, e.g. polyphenols (Ky et al., 2014). Grape seed oil is characterized by a very interesting fatty acid profile. Poly- and monounsaturated fatty acids make up $90 \%$, and linoleic acid $70 \%$, of total fatty acids (Bail et al., 2008). Research has reported that grape seed oil has strong antioxidant properties (Bloom, 2009). The average concentration of total tocopherol (vitamin E) in grape seed oil is around $454 \mathrm{mg} \cdot \mathrm{kg}^{-1}$.

Pomegranate fruits (Punica granatum, Punicaceae) are rich sources of many valuable biologically active substances besides punicic acid, e.g. flavonoids (anthocyanidins and catechins), tannins, polyunsaturated fatty acids, vitamins, polyphenols, minerals and one isoflavone - genistein (Syed et al., 2007). Pomegranate seed oil has a very interesting fatty acid profile for a component of a functional food, as its components are cis- 9 , trans- 11 , cis-13 octadecatrienoic (punicic) acid and one conjugated linolenic acid (CLnA). Pomegranate seed oil also has strong antioxidant properties (Ahmed et al., 2015). The addition of grape seed oil to broiler diets may have a positive influence on the lipid profile, cholesterol and antioxidant content in the obtained meat. In another study, feeding ducklings with grape seed oil resulted in the enrichment of their skeletal muscles by long and unsaturated fatty acids (Chaînier et al., 2000).

The addition of pomegranate seed oil to the broilers' diet has a positive effect on the lipid profile of meat and eggs, and their cholesterol content (Szymczyk and Szczurek, 2014; 2016).

The objective of present study was to evaluate the effect of the inclusion of $2 \%$ grape or pomegranate seed oil into the broilers' diets, during days $22-42$ of their lives, on the post-slaughter value and physicochemical properties of meat of broiler chickens.

\section{MATERIAL AND METHODS}

\section{Oils, animals, experimental design and diets}

Commercially available soybean oil, grape seed oil and cold pressed unrefined oil from seeds of pomegranate fruits (pomegranate seed oil) were purchased 
from the local market. They were stored at $8^{\circ} \mathrm{C}$ before the formulation of the experimental diets and subsequent feeding to chickens. The experiment was carried out on 108 one-day-old Ross 308 broilers (sex ratio 1:1). The broilers were housed in metabolic cages. For the first 5 days the temperature in the poultry house was $31^{\circ} \mathrm{C}$, and then it was gradually decreased according to the recommendations of the supplier. During the pre-experimental phase (1-21 day), all chickens were fed ad libitum the same starter type diet (Table 1) and

Table 1. Composition and nutritive value of diets, $\%$

\begin{tabular}{lcc}
\hline \multicolumn{1}{c}{ Components } & Starter period & Grower period \\
\hline Corn meal & 28.60 & 30.75 \\
Wheat meal & 28.60 & 30.75 \\
Soybean meal & 35.00 & 29.55 \\
Vegetable oil* & 3.90 & 5.00 \\
L-lysine (99\%) & 0.07 & 0.155 \\
DL-methionine (99\%) & 0.23 & 0.225 \\
Salt & 0.35 & 0.37 \\
Limestone & 1.35 & 1.45 \\
Monocalcium phosphate & 1.40 & 1.25 \\
Vitamin-mineral premix starter** & 0.50 & - \\
Vitamin-mineral premix grower** & - & 0.50 \\
Calculated nutrient per 1 kg of diets & & \\
Metabolizable energy, MJ & 12.62 & 13.02 \\
Crude protein, \% & 22.19 & 20.13 \\
Crude fibre, \% & 2.82 & 2.73 \\
Lysine, \% & 1.22 & 1.16 \\
Methionine, \% & 0.56 & 0.53 \\
Total Ca, \% & 0.95 & 0.93 \\
Available phosphorus, \% & 0.45 & 0.17 \\
Total Na, \% & 0.16 & \\
\hline
\end{tabular}

\footnotetext{
*Soybean oil.

**Vitamin-mineral premix starter provided the following nutrients per $\mathrm{kg}$ : vitamin A $24000000 \mathrm{IU}$, vitamin $\mathrm{D}_{3}-9000000 \mathrm{IU}$, vitamin $\mathrm{E}-9000 \mathrm{IU}$, vitamin $\mathrm{K}_{3}-700 \mathrm{mg}$, vitamin $\mathrm{B}_{1}-500 \mathrm{mg}$, vitamin $\mathrm{B}_{2}-1200 \mathrm{mg}$, vitamin $\mathrm{B}_{6}-800 \mathrm{mg}$, vitamin $\mathrm{B}_{12}-6000$; niacin $-8000 \mathrm{mg}$, pantothenic acid $-2600 \mathrm{mg}$, folic acid $-300 \mathrm{mg}$, biotin $-50000 \mathrm{mcg}$, choline $-70000 \mathrm{mg}, \mathrm{Cu}-$ $3500 \mathrm{mg}, \mathrm{Fe}-15000 \mathrm{mg}$, I - $350 \mathrm{mg}$, Mn - $20000 \mathrm{mg}, \mathrm{Zn}-20000 \mathrm{mg}$, Se - $55 \mathrm{mg}$.

**Vitamin-mineral premix grower provided the following nutrients per $\mathrm{kg}$ : vitamin A $2000000 \mathrm{IU}$, vitamin $\mathrm{D}_{3}-800000 \mathrm{IU}$, vitamin $\mathrm{E}-7000 \mathrm{IU}$, vitamin $\mathrm{K}_{3}-600 \mathrm{mg}$, vitamin $\mathrm{B}_{1}$ $-360 \mathrm{mg}$, vitamin $\mathrm{B}_{2}-1000 \mathrm{mg}$, vitamin $\mathrm{B}_{6}-700 \mathrm{mg}$, vitamin $\mathrm{B}_{12}-6000$; niacin $-6000 \mathrm{mg}$, pantothenic acid $-2400 \mathrm{mg}$, folic acid $-200 \mathrm{mg}$, biotin $-40000 \mathrm{mcg}$, choline $-70000 \mathrm{mg}, \mathrm{Cu}-$ $3000 \mathrm{mg}, \mathrm{Fe}-12000 \mathrm{mg}$, I - $300 \mathrm{mg}, \mathrm{Mn}-18000 \mathrm{mg}, \mathrm{Zn}-20000 \mathrm{mg}$, Se - $50 \mathrm{mg}$.
} 
water. On day 21 , each chicken $(n=108)$ was weighed and 36 birds (six replicate pens with 6 birds per pen) were randomly divided to three treatment groups and fed diets (in mashed form) for the grower period (Table 1). For the grower feeding period (22 to 42 day), the three iso-nitrogenous and iso-energetic diets were formulated according to Poultry Feeding Standards (2005). A control diet contained 5\% soybean oil (SO), whereas in the experimental diets, grape seed oil (GO) or pomegranate seed oil (PO) were included instead of $2 \%$ of the soybean oil.

\section{Slaughter procedures}

On the $42^{\text {nd }}$ day, all chickens were weighed after $12 \mathrm{~h}$ of feed deprivation and 24 representative chickens ( 8 birds from each treatment group; 4 males and 4 females) were slaughtered by cervical dislocation and the liver, gizzard and heart were weighed. Next, the $\mathrm{pH}$ value of the breast muscles was measured $45 \mathrm{~min}$ utes post-mortem $\left(\mathrm{pH}_{1}\right)$ and again after chilling the carcasses for 24 hours $\left(\mathrm{pH}_{24}\right)$. Slaughter analysis was performed according to the method described by Ziołecki and Doruchowski (1989). The breast and leg muscles from the carcass of each bird, without the skin, abdominal fat and skin with subcutaneous fat, were weighed. From the left side of each carcass, the three representative samples of the breast (pectoralis major) and thigh muscles were prepared for physicochemical and organoleptic analysis.

\section{Analysis of meat proximate composition}

The dry matter, total ash, crude protein and crude fat contents were described by the AOAC (1990) according method number: dry matter (930.15), total ash (942.05), crude protein (990.03), crude fat (991.36).

\section{Fatty acid analysis}

Samples ( $0.5 \mathrm{~g}$ for both breast and thigh muscles $)$ were taken for lipid extraction according to Folch et al. (1957). The obtained fat was taken for the preparation of fatty acid methyl esters (FAME). Fatty acid analysis was carried out by gas chromatography (GC), using a gas chromatograph (GC-17A, Shimadzu, Kyoto, Japan) with a capillary column (BPX 70; $60 \mathrm{~m} \times 0.25$ $\mathrm{mm}$ i.d., film thickness $0.20 \mu \mathrm{m}$, SGE, Ringwood, Australia) and by flame-ionization detection, with helium as the carrier gas. The validation parameters of the applied method have been presented previously (Białek et al., 2016).

\section{Lipid oxidation}

TBARs values were determined according to Shahidi et al. (1990). Absorbance was measured using a spectrophotometer at a wavelength of $532 \mathrm{~nm}$. The amount of TBARs was expressed as milligrams of malondialdehyde (MDA) per $1 \mathrm{~kg}$ of fat.

\section{Water-holding capacity (WHC)}

The WHC was determined by the press method described by Grau and Hamm (1953).

\section{$\mathrm{pH}$ of muscles}

The $\mathrm{pH}$ was measured using a standardized electrode attached to a digital $\mathrm{pH}$ meter 206.

\section{Organoleptic properties of muscles}

Organoleptic evaluation of the breast and thigh muscles was performed according to the method described by Baryłko-Pikielna and Matuszewska (2009). The sensory properties of the cooked meat were evaluated by seven individuals.

\section{Statistical analysis}

The data was subjected to one-way ANOVA generated by the Statistica version 12 package, followed posthoc by Duncan's multiple range test. The results are expressed as means, with their SD where appropriate. The data was statistically analyzed according to the following model:

where:

$$
y=\mu+a_{j}+e_{\mathrm{ij}}
$$

$\mu$ - overall mean,

$a_{j}-$ effect of treatment,

$e_{\mathrm{ij}}-$ random error.

The differences between treatment means were considered significant at $p \leq 0.05$.

\section{RESULTS}

As shown in Table 2, grape seed oil was a rich source of linoleic acid and oleic acid. Among the saturated fatty acids, palmitic acid and stearic acid were the most common. Polyunsaturated fatty acids and those 
Table 2. Fatty acid profile of grape and pomegranate seeds oil, $\%$

\begin{tabular}{|c|c|c|}
\hline Fatty acids & GO & $\mathrm{PO}$ \\
\hline $\mathrm{C}_{16: 0}$ palmitic & 7.5 & 2.8 \\
\hline $\mathrm{C}_{16: 1}$ palmitoleic & 0.1 & - \\
\hline $\mathrm{C}_{18: 0}$ stearic & 3.9 & 2.1 \\
\hline $\mathrm{C}_{18: 1} \mathrm{n}-9$ oleic & 23.5 & 5.2 \\
\hline $\mathrm{C}_{18: 1} \mathrm{n}-11$ vaccenic & 0.8 & 0.5 \\
\hline $\mathrm{C}_{18: 1}$ elaidic & 0.3 & - \\
\hline $\mathrm{C}_{18: 2}$ linoleic cis & 59.9 & 5.8 \\
\hline $\mathrm{C}_{18: 2}$ trans linoleic & 0.2 & - \\
\hline $\mathrm{C}_{18: 2} \operatorname{trans} /$ cis CLA & 0.9 & - \\
\hline $\mathrm{C}_{18: 2}$ cis/trans rumenic & 0.9 & 0.2 \\
\hline $\mathrm{C}_{18: 3} 9 \mathrm{cis}, 11$ trans, $13 \mathrm{cis}$ CLnA & - & 80.9 \\
\hline $\mathrm{C}_{18: 3} \mathrm{cis} / \mathrm{cis} / \mathrm{trans}$ & 0.1 & - \\
\hline $\mathrm{C}_{18: 3} \alpha$-linolenic & 0.6 & 0.7 \\
\hline $\mathrm{C}_{20: 0}$ arachidic & 0.3 & 0.4 \\
\hline $\mathrm{C}_{20: 1}$ eicosenic & 0.2 & 0.7 \\
\hline $\mathrm{C}_{20: 4}$ arachidonic & - & 0.3 \\
\hline $\mathrm{C}_{22: 0}$ behenic & 0.4 & - \\
\hline $\mathrm{C}_{24: 0}$ lignoceric & 0.1 & - \\
\hline$\sum \mathrm{SFA}$ & 12.2 & 5.3 \\
\hline$\sum$ MUFA & 24.9 & 6.4 \\
\hline$\sum$ PUFA & 62.6 & 87.9 \\
\hline$\sum \mathrm{CA}$ & 1.9 & 81.1 \\
\hline
\end{tabular}

GO - grape seed oil, PO - pomegranate seed oil.

containing conjugated bonds were different in these oils. The predominant fatty acid in the pomegranate seed oil was punicic acid. The most common saturated acids were palmitic and stearic acids. The proportion of $\alpha$-linolenic acid in pomegranate seed oil was similar to that of grape seed oil. Saturated and monounsaturated fatty acids made up a much lower proportion of pomegranate seed oil compared to grape seed oil. As shown in Table 3, slaughter yield did not differ significantly between the groups. The proportions of breast, thigh, shank and total muscle, abdominal fat and skin with subcutaneous fat in the carcass also did not significantly differ between treatments. The relative weights of liver, gizzard and edible giblets differed significantly between the groups (Table 3 ). The relative weight of the liver was significantly higher in the chickens fed the $2 \%$ grape seed oil diet than in the other groups. These birds had significantly larger gizzards and edible giblets than the control and GO groups. As shown in Table 4, the moisture, crude ash, crude protein and crude fat content in breast muscle did not differ significantly between the groups. 
Banaszkiewicz, T., Białek, A., Tokarz, A., Kaszperuk, K. (2018). Effect of dietary grape and pomegranate seed oil on the post-slaughter value and physicochemical properties of muscles of broiler chickens. Acta Sci. Pol. Technol. Aliment., 17(3), $199-209$. http://dx.doi.org/10.17306/J.AFS.2018.0563

Table 3. Post-slaughter characteristics of chickens at the age of 42 days

\begin{tabular}{lrcr}
\hline \multirow{2}{*}{ Specification } & \multicolumn{3}{c}{ Experimental group $( \pm \mathrm{SD})$} \\
\cline { 2 - 4 } & \multicolumn{1}{c}{$\mathrm{SO}$} & $\mathrm{GO}$ & $\mathrm{PO}$ \\
\hline Slaughter yield, \% & $73.62 \pm 1.56$ & $74.42 \pm 0.99$ & $75.17 \pm 1.20$ \\
Content in cold carcass, \% & & & \\
breast muscle & $28.49 \pm 2.68$ & $30.05 \pm 2.05$ & $29.76 \pm 2.64$ \\
thigh muscles & $12.38 \pm 1.43$ & $12.37 \pm 0.88$ & $12.75 \pm 0.86$ \\
shank muscles & $8.71 \pm 0.58$ & $8.81 \pm 0.78$ & $8.69 \pm 0.54$ \\
muscles total & $49.58 \pm 7.70$ & $51.23 \pm 1.94$ & $51.20 \pm 3.29$ \\
abdominal fat & $1.05 \pm 0.32$ & $0.93 \pm 0.28$ & $0.83 \pm 0.30$ \\
skin with subcutaneous & $10.33 \pm 1.03$ & $10.58 \pm 1.32$ & $10.56 \pm 1.44$ \\
Relative organ weight, g $\cdot 100 \mathrm{~g}^{-1}$ body weight & & & \\
heart & $0.48 \pm 0.05$ & $0.49 \pm 0.07$ & $0.46 \pm 0.07$ \\
liver & $1.63^{\mathrm{a}} \pm 0.09$ & $1.81^{\mathrm{b}} \pm 0.18$ & $1.62^{\mathrm{a}} \pm 0.17$ \\
gizzard & $1.26^{\mathrm{a}} \pm 0.06$ & $1.33^{\mathrm{a}} \pm 0.13$ & $1.13^{\mathrm{b}} \pm 0.13$ \\
edible giblets & $3.38^{\mathrm{a}} \pm 0.10$ & $3.63^{\mathrm{b}} \pm 0.30$ & $3.20^{\mathrm{a}} \pm 0.25$ \\
\hline
\end{tabular}

$\mathrm{SO}$ - soybean oil, GO - grape seed oil, PO - pomegranate seed oil.

${ }^{\mathrm{a}, \mathrm{b}}$ Values with different letters in the same row differ significantly $(p \leq 0.05)$.

The chemical composition of the thigh muscles was also similar in all groups, as was the $\mathrm{WHC}$ and $\mathrm{pH}$ of breast muscles measured at 45 minutes and 24 hours post-mortem and MDA. The effects of dietary treatment on fatty acid compositions, expressed as percentage of total methyl esters of fatty acids of the broilers' breast and thigh muscles, are shown in Tables 5 and 6 respectively. The diets supplemented with GO and PO significantly differed in the proportion of palmitic $\left(C_{16: 0}\right)$, linoleic $\left(C_{18: 2} n-6\right.$ cis LA), linolenic $\left(C_{18: 3} n-3\right.$ cis ALA), rumenic (CLA cis 9 trans 11RA), $\mathrm{C}_{20: 1}$ and $\mathrm{C}_{20: 2}$ fatty acids in breast muscles. The breast muscles of the chickens receiving feed with grape seed oil (GO - Table 5) contained significantly less palmitic acid than those from the group fed PO and slightly less than those from the control group (SO). Significantly less linoleic acid (C18:2n-6 cis LA) was found in the breast muscles of chickens receiving PO, while the greatest amount was found in the group fed a feed containing GO. The introduction of both PO and GO into the feeds significantly reduced the proportion of linolenic acid $\left(\mathrm{C}_{18 \cdot 3} \mathrm{n}-3\right.$ cis ALA) in muscles relative to the control group (SO). The inclusion of PO resulted in the deposition of conjugated punicic acid. Significant differences between the groups involved CLA isomers (especially 9c, 11t-C18:2 n-6). The introduction of $\mathrm{PO}$ into the feed increased the proportion of rumenic acid in the muscles of chickens several times. There were no significant differences in the proportions of EPA and DHA acids between the different oil groups. The inclusion of PO into the feed significantly increased the proportion of total conjugate acids and CLA acids. The most $n-6$ acids were found in the breast muscles of chickens receiving GO and the smallest amounts were found in group fed PO, while the amount of PUFA n-3 acids was significantly larger in the breast muscles of chickens from the control group (SO). In the SO group, there was also a significantly lower ratio of n-6/n-3 acids, especially compared to those receiving GO.

In the thigh muscle, there were significant differences regarding 13 acids (Table 6). Significantly less 
Banaszkiewicz, T., Białek, A., Tokarz, A., Kaszperuk, K. (2018). Effect of dietary grape and pomegranate seed oil on the post-slaughter value and physicochemical properties of muscles of broiler chickens. Acta Sci. Pol. Technol. Aliment., 17(3), $199-209$. http://dx.doi.org/10.17306/J.AFS.2018.0563

Table 4. Results of physico-chemical estimation of muscles

\begin{tabular}{llll}
\hline \multirow{2}{*}{ Specification } & \multicolumn{3}{c}{ Experimental group } \\
\cline { 2 - 4 } & \multicolumn{1}{c}{$\mathrm{SO}$} & $\mathrm{GO}$ & \multicolumn{1}{c}{ PO } \\
\hline Breast muscle & & & \\
Dry matter, \% & $26.07 \pm 0.54$ & $25.81 \pm 0.30$ & $25.57 \pm 0.58$ \\
Crude ash, \% & $1.16 \pm 0.04$ & $1.16 \pm 0.02$ & $1.16 \pm 0.01$ \\
Crude protein, \% & $22.37 \pm 0.54$ & $22.66 \pm 0.44$ & $22.04 \pm 0.68$ \\
Crude fat, \% & $1.51 \pm 0.26$ & $1.57 \pm 0.60$ & $1.73 \pm 0.36$ \\
Absorbability, \% & $13.12 \pm 4.17$ & $16.16 \pm 5.31$ & $15.95 \pm 3.75$ \\
pH ${ }_{45}$ & $5.36 \pm 0.11$ & $5.40 \pm 0.13$ & $5.52 \pm 0.19$ \\
pH ${ }_{24}$ & $5.43 \pm 0.12$ & $5.41 \pm 0.11$ & $5.38 \pm 0.16$ \\
Thigh muscles & & & \\
Dry matter,\% & $25.59 \pm 0.75$ & $25.34 \pm 0.33$ & $25.45 \pm 0.42$ \\
Crude ash,\% & $1.09 \pm 0.02$ & $1.10 \pm 0.02$ & $1.09 \pm 0.03$ \\
Crude protein,\% & $19.16 \pm 0.49$ & $19.69 \pm 0.69$ & $19.13 \pm 0.38$ \\
Crude fat,\% & $4.70 \pm 0.29$ & $4.41 \pm 0.60$ & $5.08 \pm 0.46$ \\
Absorbability,\% & $9.89 \pm 4.58$ & $8.09 \pm 4.61$ & $9.61 \pm 4.99$ \\
MDA, mg kg-1 fat & $0.51 \pm 0.04$ & $0.40 \pm 0.07$ & $0.37 \pm 0.05$ \\
\hline
\end{tabular}

$\mathrm{SO}$-soybean oil, GO-grape seed oil, $\mathrm{PO}$ - pomegranate seed oil.

palmitic acid was found in the muscles of chickens from the GO group and PO group. The introduction of both oils (from grape and pomegranate seeds) significantly decreased the proportion of palmitoleic acid and the pomegranate seed oil significantly decreased the proportion of oleic acid. The introduced PO significantly enriched the thigh muscle with EPA acid. Significant differences between the groups (Table 6) were found for all calculated acid totals, except for saturated fatty acids. A reduction in the total amount of monounsaturated acids (MUFA) and an increase in polyunsaturated acids (PUFA) were observed after the use of both GO and PO. Significant increases in CLA acid (mainly c9 t11) and total conjugate acids were observed after the introduction of PO. The most of $\mathrm{n}-6$ acids were found in the thigh muscles of chickens from the GO group, and the most $\mathrm{n}-3$ acids were found in the control group (SO).
Table 5. Fatty acid profile of breast muscle, $\%$ of total acids

\begin{tabular}{|c|c|c|c|}
\hline \multirow{2}{*}{ Fatty acids } & \multicolumn{3}{|c|}{ Experimental group } \\
\hline & $\mathrm{SO}$ & GO & $\mathrm{PO}$ \\
\hline $\mathrm{C}_{12: 0}$ & $0.04 \pm 0.02$ & $0.04 \pm 0.01$ & $0.04 \pm 0.01$ \\
\hline $\mathrm{C}_{14: 0}$ & $0.46 \pm 0.08$ & $0.40 \pm 0.08$ & $0.40 \pm 0.09$ \\
\hline $\mathrm{C}_{14: 1}$ & $0.07 \pm 0.04$ & $0.05 \pm 0.03$ & $0.06 \pm 0.02$ \\
\hline $\mathrm{C}_{15: 0}$ & $0.11 \pm 0.03$ & $0.09 \pm 0.02$ & $0.10 \pm 0.03$ \\
\hline $\mathrm{C}_{16: 0}$ & $19.64^{\mathrm{ab}} \pm 1.30$ & $18.65^{\mathrm{a}} \pm 0.78$ & $20.19^{b} \pm 1.01$ \\
\hline $\mathrm{C}_{16: 1}$ & $2.64 \pm 1.26$ & $1.90 \pm 0.90$ & $2.15 \pm 0.53$ \\
\hline $\mathrm{C}_{17: 0}$ & $0.27 \pm 0.04$ & $0.28 \pm 0.05$ & $0.23 \pm 0.04$ \\
\hline $\mathrm{C}_{17: 1}$ & $0.07 \pm 0.02$ & $0.06 \pm 0.02$ & $0.06 \pm 0.04$ \\
\hline $\mathrm{C}_{18: 0}$ & $8.94 \pm 1.44$ & $9.75 \pm 1.78$ & $9.66 \pm 0.78$ \\
\hline $\mathrm{C}_{18: 1} \mathrm{n}-9$ trans & $0.26 \pm 0.12$ & $0.19 \pm 0.04$ & $0.24 \pm 0.03$ \\
\hline$C_{18: 1} n-9$ cis OL & $22.08 \pm 2.67$ & $20.66 \pm 3.41$ & $19.76 \pm 2.23$ \\
\hline$C_{18: 2} n-6$ cis LA & $25.54^{\mathrm{a}} \pm 3.47$ & $27.22^{\mathrm{a}} \pm 3.19$ & $21.75^{\mathrm{b}} \pm 2.11$ \\
\hline $\mathrm{C}_{18: 2} \mathrm{n}-6$ trans & $0.50 \pm 0.20$ & $0.63 \pm 0.19$ & $0.49 \pm 0.17$ \\
\hline$C_{18: 3}$ n-6 GLA & $0.17 \pm 0.04$ & $0.18 \pm 0.05$ & $0.15 \pm 0.02$ \\
\hline $\mathrm{C}_{18: 3} \mathrm{n}-3$ ALA & $2.08^{\mathrm{a}} \pm 0.89$ & $1.39^{\mathrm{b}} \pm 0.39$ & $1.38^{\mathrm{b}} \pm 0.26$ \\
\hline CLnA, PA & - & - & $0.56 \pm 0.20$ \\
\hline $\mathrm{C}_{20: 0}$ & $0.07 \pm 0.01$ & $0.07 \pm 0.01$ & - \\
\hline $\begin{array}{l}\text { CLA cis9 } \\
\text { trans } 11 \text { RA }\end{array}$ & $0.03^{\mathrm{a}} \pm 0.01$ & $0.12^{\mathrm{a}} \pm 0.02$ & $5.04^{b} \pm 0.53$ \\
\hline $\mathrm{C}_{20: 1}$ & $0.24^{\mathrm{a}} \pm 0.01$ & $0.22^{\mathrm{a}} \pm 0.05$ & $0.29^{b} \pm 0.03$ \\
\hline $\mathrm{C}_{20: 2}$ & $0.08^{\mathrm{ab}} \pm 0.03$ & $0.06^{\mathrm{a}} \pm 0.01$ & $0.12^{b} \pm 0.06$ \\
\hline$C_{20: 3} n-6$ & $0.71 \pm 0.22$ & $0.81 \pm 0.28$ & $0.92 \pm 0.24$ \\
\hline$C_{20: 4} n-6 A A$ & $4.70 \pm 2.22$ & $6.21 \pm 1.76$ & $4.61 \pm 1.24$ \\
\hline$C_{20: 5} n-3$ EPA & $0.26 \pm 0.10$ & $0.24 \pm 0.08$ & $0.21 \pm 0.09$ \\
\hline $\mathrm{C}_{21: 0}$ & $0.80 \pm 0.33$ & $0.88 \pm 0.29$ & $0.61 \pm 0.20$ \\
\hline $\mathrm{C}_{22: 0}$ & $0.03 \pm 0.01$ & $0.04 \pm 0.02$ & $0.02 \pm 0.01$ \\
\hline$C_{22: 1} n-9$ & $0.02 \pm 0.00$ & $0.02 \pm 0.00$ & $0.02 \pm 0.01$ \\
\hline $\mathrm{C}_{22: 6} \mathrm{n}-3$ DHA & $0.50 \pm 0.19$ & $0.49 \pm 0.19$ & $0.41 \pm 0.13$ \\
\hline $\mathrm{C}_{23: 0}$ & $0.05 \pm 0.01$ & $0.06 \pm 0.02$ & $0.07 \pm 0.00$ \\
\hline$\sum \mathrm{SFA}$ & $30.41 \pm 2.25$ & $30.26 \pm 2.21$ & $31.32 \pm 0.72$ \\
\hline$\sum$ MUFA & $25.39 \pm 3.68$ & $23.10 \pm 4.32$ & $22.58 \pm 2.72$ \\
\hline$\sum$ PUFA & $34.57 \pm 2.77$ & $37.35 \pm 2.71$ & $35.64 \pm 2.41$ \\
\hline$\sum$ CLA & $0.03^{\mathrm{a}} \pm 0.01$ & $0.12^{\mathrm{a}} \pm 0.02$ & $5.04^{b} \pm 0.53$ \\
\hline$\sum \mathrm{CA}$ & $0.03^{\mathrm{a}} \pm 0.01$ & $0.12^{\mathrm{a}} \pm 0.01$ & $5.65^{\mathrm{b}} \pm 0.59$ \\
\hline$\sum n-6$ & $31.62^{\mathrm{a}} \pm 2.37$ & $35.05^{\mathrm{b}} \pm 2.55$ & $27.92^{\mathrm{c}} \pm 1.86$ \\
\hline$\sum n-3$ & $2.84^{\mathrm{a}} \pm 0.70$ & $2.12^{\mathrm{b}} \pm 0.20$ & $2.00^{b} \pm 0.39$ \\
\hline$n-6 / n-3$ & $\begin{array}{c}11.13^{\mathrm{a}}: 1 \\
\pm 2.29\end{array}$ & $\begin{array}{l}16.53^{\mathrm{b}}: 1 \\
\pm 1.04\end{array}$ & $\begin{array}{c}13.96^{\mathrm{c}}: 1 \\
\quad \pm 1.18\end{array}$ \\
\hline
\end{tabular}

$\mathrm{SO}$ - soybean oil, GO - grape seed oil, PO - pomegranate seed oil.

${ }^{a, b}$ Values with different letters in the same row differ significantly $(p \leq 0.05)$. 
Banaszkiewicz, T., Białek, A., Tokarz, A., Kaszperuk, K. (2018). Effect of dietary grape and pomegranate seed oil on the post-slaughter value and physicochemical properties of muscles of broiler chickens. Acta Sci. Pol. Technol. Aliment., 17(3), $199-209$. http://dx.doi.org/10.17306/J.AFS.2018.0563

Table 6. Fatty acid profile of thigh muscles, $\%$ of total acids

\begin{tabular}{|c|c|c|c|}
\hline \multirow{2}{*}{ Fatty acids } & \multicolumn{3}{|c|}{ Experimental group } \\
\hline & $\mathrm{SO}$ & GO & $\mathrm{PO}$ \\
\hline $\mathrm{C}_{12: 0}$ & $0.06 \pm 0.02$ & $0.05 \pm 0.01$ & $0.05 \pm 0.02$ \\
\hline $\mathrm{C}_{14: 0}$ & $0.47 \pm 0.12$ & $0.42 \pm 0.03$ & $0.40 \pm 0.04$ \\
\hline $\mathrm{C}_{14: 1}$ & $0.08 \pm 0.01$ & $0.06 \pm 0.02$ & $0.06 \pm 0.03$ \\
\hline $\mathrm{C}_{15: 0}$ & $0.09 \pm 0.03$ & $0.09 \pm 0.01$ & $0.09 \pm 0.01$ \\
\hline $\mathrm{C}_{16: 0}$ & $20.32^{\mathrm{a}} \pm 1.59$ & $18.20^{\mathrm{b}} \pm 2.12$ & $19.88^{\mathrm{a}} \pm 0.73$ \\
\hline $\mathrm{C}_{16: 1}$ & $3.26^{\mathrm{a}} \pm 0.46$ & $2.53^{\mathrm{b}} \pm 0.51$ & $2.50^{\mathrm{b}} \pm 0.88$ \\
\hline $\mathrm{C}_{17: 0}$ & $0.30^{\mathrm{a}} \pm 0.03$ & $0.32^{\mathrm{a}} \pm 0.32$ & $0.25^{\mathrm{b}} \pm 0.03$ \\
\hline $\mathrm{C}_{17: 1}$ & $0.08 \pm 0.01$ & $0.07 \pm 0.01$ & $0.05 \pm 0.01$ \\
\hline $\mathrm{C}_{18: 0}$ & $8.09 \pm 1.38$ & $8.08 \pm 1.66$ & $9.48 \pm 1.31$ \\
\hline $\mathrm{C}_{18: 1} \mathrm{n}-9$ trans & $0.28 \pm 0.13$ & $0.23 \pm 0.11$ & $0.27 \pm 0.04$ \\
\hline$C_{18: 1} n-9$ cis & $26.15^{\mathrm{a}} \pm 3.51$ & $23.81^{\mathrm{ab}} \pm 4.10$ & $20.42^{b} \pm 3.58$ \\
\hline$C_{18: 2} n-6$ cis LA & $27.47^{a} \pm 3.32$ & $31.39^{b} \pm 3.75$ & $23.89^{c} \pm 1.45$ \\
\hline $\mathrm{C}_{18: 2} \mathrm{n}-6$ trans & $0.32 \pm 0.15$ & $0.40 \pm 0.16$ & $0.37 \pm 0.17$ \\
\hline $\mathrm{C}_{18: 3} \mathrm{n}-6 \mathrm{GLA}$ & $0.16^{\mathrm{ab}} \pm 0.03$ & $0.19^{\mathrm{a}} \pm 0.04$ & $0.14^{b} \pm 0.01$ \\
\hline $\mathrm{C}_{18: 3} \mathrm{n}-3 \mathrm{ALA}$ & $2.25^{\mathrm{a}} \pm 0.60$ & $1.86^{\mathrm{ab}} \pm 0.42$ & $1.48^{\mathrm{b}} \pm 0.32$ \\
\hline $\mathrm{C}_{18: 3} \mathrm{CLn} \mathrm{A}$ & - & - & $0.40 \pm 0.07$ \\
\hline $\mathrm{C}_{20: 0}$ & $0.09 \pm 0.01$ & $0.07 \pm 0.01$ & - \\
\hline $\begin{array}{l}\text { CLA cis9 } \\
\text { trans11 RA }\end{array}$ & $0.03^{\mathrm{a}} \pm 0.01$ & $0.13^{\mathrm{a}} \pm 0.02$ & $4.96^{\mathrm{b}} \pm 0.53$ \\
\hline $\mathrm{C}_{20: 1}$ & $0.26^{\mathrm{a}} \pm 0.03$ & $0.26^{\mathrm{a}} \pm 0.03$ & $0.31^{\mathrm{b}} \pm 0.03$ \\
\hline $\mathrm{C}_{20: 2}$ & $0.49^{\mathrm{a}} \pm 0.10$ & $0.05^{\mathrm{b}} \pm 0.01$ & $0.10^{\mathrm{b}} \pm 0.04$ \\
\hline$C_{20: 3} n-6$ & $0.39^{\mathrm{a}} \pm 0.08$ & $0.60^{\mathrm{b}} \pm 0.23$ & $0.79^{b} \pm 0.24$ \\
\hline$C_{20: 3} n-3$ & $0.12 \pm 0.05$ & $0.11 \pm 0.04$ & $0.16 \pm 0.09$ \\
\hline$C_{20: 4} n-6$ AA & $2.79 \pm 0.05$ & $3.45 \pm 1.32$ & $3.97 \pm 1.24$ \\
\hline$C_{20: 5} n-3$ EPA & $0.12^{\mathrm{a}} \pm 0.06$ & $0.11^{\mathrm{a}} \pm 0.03$ & $0.18^{\mathrm{b}} \pm 0.06$ \\
\hline $\mathrm{C}_{21: 0}$ & $0.01 \pm 0.00$ & $0.61 \pm 0.16$ & $0.45 \pm 0.16$ \\
\hline $\mathrm{C}_{22: 0}$ & $0.04 \pm 0.01$ & $0.03 \pm 0.00$ & $0.04 \pm 0.01$ \\
\hline$C_{22: 1} n-9$ & $0.02^{\mathrm{a}} \pm 0.00$ & $0.02^{\mathrm{a}} \pm 0.00$ & $0.06^{\mathrm{b}} \pm 0.02$ \\
\hline $\mathrm{C}_{22: 6} \mathrm{n}-3$ DHA & $0.25 \pm 0.10$ & $0.27 \pm 0.11$ & $0.37 \pm 0.14$ \\
\hline$\sum \mathrm{SFA}$ & $29.54 \pm 2.91$ & $27.97 \pm 3.69$ & $30.64 \pm 1.39$ \\
\hline$\sum$ MUFA & $30.13^{a} \pm 3.80$ & $26.98^{\mathrm{ab}} \pm 4.48$ & $23.67^{b} \pm 4.40$ \\
\hline$\sum$ PUFA & $34.40^{\mathrm{a}} \pm 3.07$ & $38.57^{\mathrm{b}} \pm 3.42$ & $37.03^{\mathrm{ab}} \pm 2.08$ \\
\hline$\sum$ CLA & $0.03^{\mathrm{a}} \pm 0.01$ & $0.13^{\mathrm{a}} \pm 0.02$ & $4,96^{\mathrm{b}} \pm 0.53$ \\
\hline$\sum \mathrm{CA}$ & $0.03 \pm 0.01$ & $0.13 \pm 0.02$ & $5.36 \pm 0.51$ \\
\hline$\sum \mathrm{n}-6$ & $31.13^{\mathrm{a}} \pm 2.57$ & $36.03^{b} \pm 3.15$ & $29.16^{c} \pm 2.03$ \\
\hline$\sum \mathrm{n}-3$ & $2.74^{\mathrm{a}} \pm 0.52$ & $2.35^{\mathrm{b}} \pm 0.31$ & $2.19^{\mathrm{b}} \pm 0.25$ \\
\hline$n-6 / n-3$ & $\begin{array}{c}11.36^{\mathrm{a}}: 1 \\
\pm 1.51\end{array}$ & $\begin{array}{l}15.33^{\mathrm{b}}: 1 \\
\quad \pm 1.25\end{array}$ & $\begin{array}{l}13.31^{\mathrm{c}}: 1 \\
\quad \pm 1.88\end{array}$ \\
\hline
\end{tabular}

$\mathrm{SO}$ - soybean oil, GO - grape seed oil, $\mathrm{PO}$ - pomegranate seed oil.

a,bValues with different letters in the same row differ significantly $(p \leq 0.05)$.

\section{Organoleptic evaluation of muscles}

Analysis of the results of the organoleptic evaluation of the breast muscle (Fig. 1) showed no significant differences between the groups for any of the evaluated parameters. Significant differences were found in the palatability of thigh muscles (Fig. 2). Significantly better $(p \leq 0.05)$ palatability characterized the thigh muscles of chickens fed diets containing GO and PO.

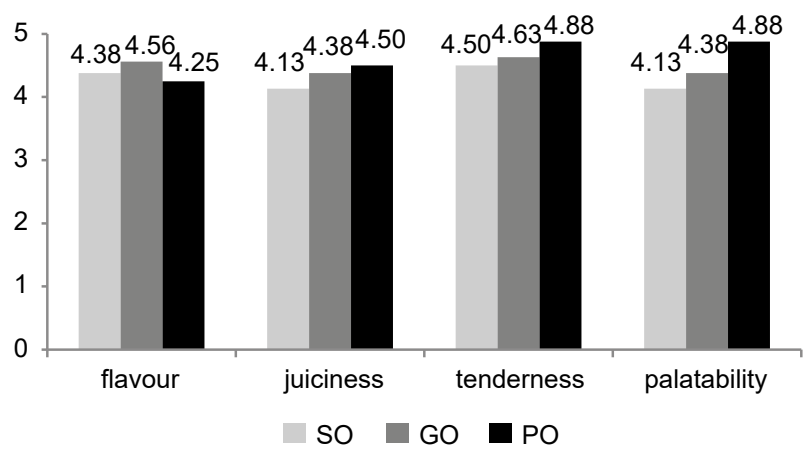

Fig. 1. Sensory evaluation of breast muscle, scores

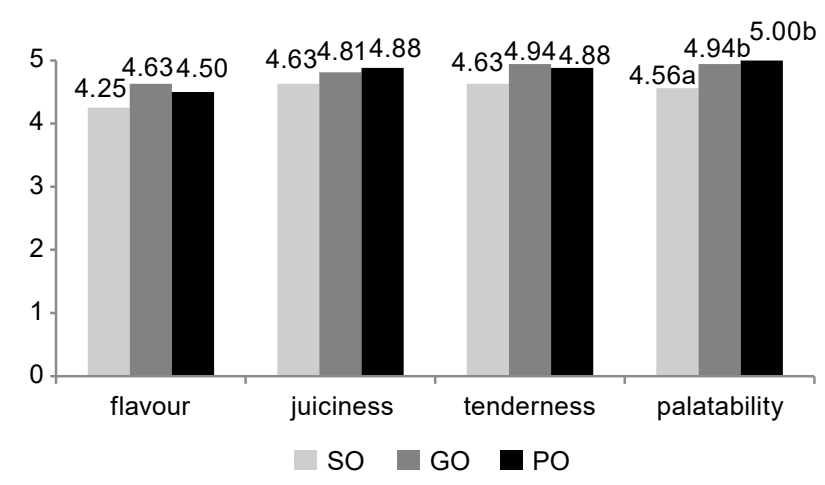

Fig. 2. Sensory evaluation of thigh muscle, scores. Significant differences indicated various letters

\section{DISCUSSION}

Meat quality is an important issue in modern poultry production and processing, due to consumer concerns about the impact of meat and functional foods on their health and wellbeing (Attia et al., 2010; 2017a; 2017b). The present study indicated significant changes in the 
relative weights of the liver, gizzard and edible giblets among the groups. However, the slaughter yield, proportions of breast, thigh, shank and total muscle, abdominal fat and skin with subcutaneous fat in the carcasses did not differ between treatments (Table 3). Szymczyk and Szczurek (2016) found that replacing SO with PO and linseed oil in chicken diets did not cause differences in carcass yield, breast and leg muscles, liver, gizzard and heart in the body weight of chickens. In addition, Jankowski et al. (2012) observed no differences in slaughter yield and breast, thigh and drumstick muscle yield in turkeys fed diets with soybean, linseed and rapeseed oils. Hajati et al. (2015) also did not find any influence of grape seed extract of 150,300 and $450 \mathrm{mg} / \mathrm{kg}$ of the diet on the percentage share of edible carcass, stomach, liver, breast, drumstick and thighs, and deposition of abdominal fat. The use of PO and GO in the present study did not significantly affect $\mathrm{pH}_{1}$ and $\mathrm{pH}_{24}$ of breast muscles, but the addition of $\mathrm{PO}$ and GO numerically decreased malondialdehyde (MDA) content in the thigh muscles. Al-Qazzaz (2014) reports that the immersion of minced poultry meat in pomegranate peel extract resulted in a significant $(p \leq 0.05)$ decrease in water-holding capacity (WHC), $\mathrm{pH}$ and the content of thiobarbituric acid (TBA index) and a reduction in water loss of the stored meat. They suggested that the quality of poultry meat stored for 6 weeks at $-18^{\circ} \mathrm{C}$ can be improved by immersion in pomegranate peel extract. On the other hand, Szymczyk and Szczurek (2014) did not observe any significant influence of $\mathrm{PO}$ on the content of MDA in meat. Moreover, Zduńczyk and Jankowski (2013) found that the use of linseed oil in turkey' feeds may increase the content of PUFA in meat, and resulted in a decrease in oxidative stability of the meat and a deterioration of sensory characteristics.

The present results show an increase in the proportion of PUFA acids and a decrease in MUFA in muscles due to GO. Similarly, Chamorro et al. (2015) observed that the addition of grape pomace to the feed in amounts of $5 \%$ and $10 \%$ resulted in an increase in the content of PUFA acids and a reduction of MUFA in the chicken' thigh muscles. According to Szymczyk and Szczurek (2016), as a result of increasing the proportion of $\mathrm{PO}$ in feeds, there is an increase in the proportion of PUFA and a decrease in the proportion of MUFA in the breast muscles of chickens, as well as an increase in the proportion of CLA acids, which is consistent with the results obtained herein.

As Szymczyk and Szczurek (2014) claim, the breast muscle can be enriched with CLA isomers and meat quality can be maintained by introducing PO into feeds for broiler chickens. Attia et al. (2015) found similar results with broiler chickens. Kohno et al. (2004) ascertained that the punicic acid (CLnA) contained in PO did not form deposits in the livers of rats, but was transformed by the intestinal microflora into rumenic acid (RA), the amount of which increased in the liver along with the amount of PO. This may be due to the fact that punicic acid is slowly absorbed in the intestine and, in various tissues, may be converted into cis- 9 , trans- $11 \mathrm{C}_{18: 2}$ isomer, and, therefore, pomegranate seed oil can be called an indirect source of CLA.

The palatability of meat is largely determined by the fatty acid profile. In the present study, no significant differences were found in the organoleptic traits of breast muscles, whereas the thigh muscles of chickens fed feeds containing both GO and PO were characterized by a significantly better taste. However, Kostecka and Łobacz (2009) claim that linoleic acid has a particular impact on the aroma of meat, but warn that the addition of significant quantities of rapeseed or linseed oil and fish meal may result in a fishy flavour and taste in the poultry meat.

\section{CONCLUSION}

The current study showed that the type of oil used did not have a significant impact on the slaughter yield, fatness and musculature ratio of chickens, while PO significantly decreased the proportion of liver, gizzard and edible giblet in the body weight of the chickens compared to those receiving GO. The type of oil did not affect the physicochemical properties (basic composition, water-holding capacity, $\mathrm{pH}$ value and content of MDA) of muscles, but significantly altered the profile of fatty acids and PO (2\%) and improved the palatability of the thigh muscle. The punicic acid (CLnA) contained in the PO was deposited in the muscles in small amounts, but was effectively converted to rumenic acid (RA), which resulted in the meat being enriched with health-promoting fatty acids. Based on these findings, it can be concluded that inclusion of 
Banaszkiewicz, T., Białek, A., Tokarz, A., Kaszperuk, K. (2018). Effect of dietary grape and pomegranate seed oil on the post-slaughter value and physicochemical properties of muscles of broiler chickens. Acta Sci. Pol. Technol. Aliment., 17(3), $199-209$. http://dx.doi.org/10.17306/J.AFS.2018.0563

$\mathrm{GO}$ and $\mathrm{PO}$ into the feed may be a promising method to improve the quality of broiler chicken meat and the derived "functional food". It could also be a way to give people better quality food without changing their eating habits.

\section{REFERENCES}

Abrones-Mainar, J. M., Navarro, M. A., Guzman, M. A., Arnal, C., Surra, J. C., Acin, S., Carnicer, R., Osada, J., Roche, H. (2006). Selective effect of conjugated linoleic acid isomers on atherosclerotic lesion development in apolipoprotein E knockout mice. Atherosclerosis, 189(2), 318-327.

Ahmed, S. T., Islam, M. M., Bostami, A. B. M. R., Mun, H. S., Kim, Y. J., Yang, C. J. (2015). Meat composition, fatty acid profile and oxidative stability of meat from broilers supplemented with pomegranate (Punica granatum L.) by-products. Food Chem., 188, 481-488. http://dx.doi.org/10.1016/j.foodchem.2015.04.140

Al-Qazzaz, M. F. (2014). The effect of using pomegranate peel extract on the quality and chemical characteristics for minced frozen spent chicken meat. Diyala Agric. Sci. J., 6(1), 1-10.

AOAC (1990). Official methods of analysis. Association of Official Analytical Chemists. 14th ed. Washington, DC, USA: AOAC International.

Attia, Y. A., Abdalah, A. A., Zeweil, H. S., Bovera, F., Tag El-Din, A. A., Araft, M. A. (2010). Effect of inorganic or organic selenium supplementation on productive performance, egg quality and some physiological traits of dual purpose breeding hens. Czech J. Anim. Sci., 55, 505-519.

Attia, Y. A., Al-Harthi, M. A., Korish, M. M., Shiboob, M. M. (2015). Fatty acid and cholesterol profiles and hypocholesterolemic, atherogenic, and thrombogenic indices of table eggs in the retail market. Lipids Health Dis., 14, 136. http://dx.doi.org/10.1186/s12944-015-0133-z

Attia, Y. A., Al-Harthi, M. A., Korish, M. M., Shiboob, M. M. (2017a). Fatty acid and cholesterol profiles, hypocholesterolemic, atherogenic, and thrombogenic indices of broiler meat in the retail market. Lipids Health Dis., 14, 16, 40, 1-11. http://dx.doi.org/10.1186/ s12944-017-0423-8

Attia, Y. A., Bovera, F., Abd-El-Hamid, A. E., Tag El-Din, A. E., Al-Harthi, M. A., Nizza, A., Elharidy, R. M. (2017b). Effect of dietary protein concentrations, amino acids and conjugated linoleic acid supplementations on productive performance and lipid metabolism of broiler chicks. Italian J Anim. Sci., 16, 4, 563-572. https://doi. org/10.1080/1828051X.2017.1301228

Bail, S., Stuebiger, G., Krist, S., Unterweger, H., Buchbauer, G. (2008). Characteristic of various grape seed oils by volatile compounds, triacylglycerol composition, total phenols and antioxidant capacity. Food Chem., 108, 1122-1132.

Banaszkiewicz, T. (2002). Wpływ oleju rzepakowego na skład frakcji lipidowych u kurcząt brojlerów [Effect of rapeseed oil on the composition of lipid fractions in broiler chickens]. Rocz. Nauk. Zoot. Supl., 16, 179-184 [in Polish].

Baryłko-Pikielna, N., Matuszewska, I. (2009). Sensoryczne badania żywności. Podstawy, metody, zastosowanie [Sensory analysis of food. Basics, methods, applications]. Kraków: Wyd. Nauk. PTTŻ [in Polish].

Białek, A., Jelińska, M., Tokarz, A., Pergół, A., Pinkiewicz, K. (2016). Influence of pomegranate seed oil and bitter melon aqueous extract on polyunsaturated fatty acids and their lipoxygenase metabolites concentration in serum of rats. Prostagl. Other Lipid Mediat., 126, 29-37. http://dx.doi.org/10.1016/j.prostaglandins.2016.07.005

Bloom, R. Z. (2009). Antioxidant and anti-proliferative properties of selected grape seed extracts. Unpublished doctoral dissertation. Faculty of the School of the University of Maryland, Collage Park. ProQuest Dissertation Publishing, 1467653. www.lib.umd.edu/drum/bitstream/1903/Bloom_umd_0117N_10367.pdf

Bhattacharya, A., Banu, J., Rahman, M., Causey, J., Fernandes, G. (2006). Biological effects of conjugated linoleic acids in health and disease. J. Nutr. Biochem., 17(12), 789-810.

Chaînier, F., Roussel, D., Georges, B., Meister, R., Rouanet, J. L., Duchamp, C., Barre, H. (2000). Cold acclimation or grapeseed oil feeding affects phospholipid composition and mitochondrial function in duckling skeletal muscle. Lipids, 35, 1099-1106. http://dx.doi. org/10.1007/s11745-000-0625-8

Chamorro, S., Viveros, A., Rebolé, A., Rica, B. D., Arija, I., Brenes, A. (2015). Influence of dietary enzyme addition on polyphenol utilization and meat lipid oxidation of chicks fed grape pomace. Food Res. Int., 73, 197-203.

Folch, J., Lees, M., Sloane-Stanley, G. H. (1957). A simple method for the isolation and purification of total lipids from animal tissues. J. Biol. Chem., 226, 497-509.

Grau, R., Hamm, G. (1953). Eine Einfache Methodezur Bestimmung der Wasserbindung in Muscel. Naturwissenchaften, 40(1), 259-277.

Hajati, H., Hassanabadi, A., Golian, A. G., Nassiri-Moghaddam, H., Nassiri, M. R. (2015). The effect of grape seed 
extract and vitamin $\mathrm{C}$ feed supplements carcass characteristics, gut morphology and ileal microflora in broiler chickens exposed to chronic heat stress. Iran J. Anim. Sci., 5(1), 155-165.

Jankowski, J., Zdunczyk, Z., Mikulski, D., Juskiewicz, J., Naczmanski, J., Pomianowski, J. F., Zdunczyk, P. (2012). Fatty acid profile, oxidative stability and sensory properties of breast meat from turkeys fed diets with a different n-6/n-3 PUFA ratio. Eur. J. Lipid Sci. Technol., 114, 9, 1025-1035.

Kohno, H., Suzuki, R., Yasui, Y., Miyashita, K., Tanaka, T. (2004). Pomegranate seed oil rich in conjugated linolenic acid suppresses chemically induced colon carcinogenesis in rats. Cancer Sci., 95, 481-486.

Kostecka, M., Łobacz, M. (2009). Lipids from chicken fat invaluable (underestimated) fat. Part I. Chicken fat characteristic and chosen modification methods. Technol. Progress Food Proc., 1, 98-103.

Ky, I., Lorrain, B., Kolbas, N., Crozier, A., Teissedre, P. L. (2014). Wine by-products: phenolic characterization and antioxidant activity evaluation of grapes and grape pomaces from six different French grape varieties. Molecules (Basel, Switzerland), 19, 482-506.

Lopez-Ferrer, S., Baucells, M. D., Barroeta, A. C., Galobart, J., Grashorn, M. A. (2001). n-3 Enrichment of chicken meat. 2. Use of precursors of long-chain polyunsaturated fatty acids: Linseed oil. Poult. Sci., 42, 368-375.
Poultry Feeding Standards (2005). Warszawa: IFiŻZ PAN.

Shahidi, F. (1990). The 2-thiobarbituric acid (TBA) methodology for the evaluation of warmed-over flavour and rancidity in meat products. 36th Int. Conf. Meat Sci. Technol., Havana, Cuba 1990 (pp. 1008-1014).

Syed, D. B., Afaq, F., Mukhtar, H. (2007). Pomegranate derived products for cancer chemoprevention. Semin. Cancer Biol., 17, 377-385.

Szymczyk, B., Szczurek, W. (2014). Effect of dietary pomegranate seed oil on quality of broiler chicken meat. In: Conference Materials from XXVII International Poultry Symposium PB WPSA "Science to practice - practice to science" 2014. 8-10.09.2014. Kazimierz Dolny nad Wisłą, Poland.

Szymczyk, B., Szczurek, W. (2016). Effect of dietary pomegranate seed oil and linseed oil on broiler chickens performance and meat fatty acid profile. J. Anim. Feed Sci., 25, 37-44.

Zduńczyk, Z., Jankowski, J. (2013). Poultry meat as functional food: Modification of the fatty acid profile - a review. Ann. Anim. Sci., 13(3), 463-480.

Ziołecki, J., Doruchowski, W. (1989). Metody oceny wartości rzeźnej drobiu [The method of estimation of poultry slaughter analysis]. Poznań: Wyd. COBRD [in Polish]. 